\title{
PERAN SEKTOR PARIWISATA TERHADAP PENDAPATAN ASLI DAERAH DI KABUPATEN LAMONGAN
}

\section{Efeni Nuri Fauziyah Fitriyah*, M. Faisal Abdullah, M. Sri Wahyudi Suliswanto}

Program Studi Ekonomi Pembangunan, Fkaultas Eknomi dan Bisnis, Universitas Muhammadiyah Malang, Jl.Raya Tlogomas No.246 Malang, Indonesia

* Corresponding author: fenynuri13@gmail.com

\begin{tabular}{ll}
\hline Artikel Info & Abstract \\
\cline { 3 - 3 } Article history: & The purpose of this study was to analyze the influence of the \\
Received 25 November 2019 & Number of Travelers, Number of Tourism Objects and \\
Revised 5 December 2019 & Number of Hotel Visitors to the Local Revenue of the \\
Accepted 10 January 2020 & Lamongan Regency. This type of research uses quantitative \\
Available online 15 February & research, which uses data published by the Lamongan Regency \\
2020 & Central Bureau of Statistics. Then analyzed using Multiple \\
& Linear regression analysis processed using Eviews 9. The \\
Keyword: Number of tourists, & research results in the first regression show that the number of \\
Number of tourist attractions, & tourists does not significantly influence the original income of \\
Number of Hotel Visitors and & the Lamongan Regency with a coefficient of -1.66E + 08. The \\
PAD. & results of the second regression show that the number of tourism \\
& objects has a significant positive influence on the original \\
income of the Lamongan Regency region with a coefficient of \\
JEL Classification & 74620851 and for the third regression result indicates that the \\
C23, D00, F02, F15 & variable number of hotel visitors also has a positive but not \\
& significant effect on the regional income the coefficient value is \\
\hline
\end{tabular}

\section{PENDAHULUAN}

Dalam konteks pembangunan, bangsa Indonesia sejak lama telah mencanangkan suatu gerakan pembangunan yang dikenal dengan istilah pembangunan nasional. Pembangunan nasional adalah kegiatan yang berlangsung terus menerus dan berkesinambungan yang bertujuan untuk meningkatkan kesejahteraan rakyat baik yang bersifat materiil maupun spiritual. Dalam rangka pembangunan nasional di Indonesia, pembangunan daerah yang merupakan bagian integral dari pembangunan nasional diarahkan untuk mengembangkan daerah dan menyelaraskan laju pertumbuhan antar daerah dan pembangunan tersebut disesuaikan dengan prioritas dan potensi daerah masing-masing untuk meningkatkan kemampuan daerah tersebut.

Kebijakan otonomi daerah yang secara resmi mulai diberlakukan di Indonesia sejak 1 Januari 2001, menghendaki masing-masing daerah dituntut untuk berupaya meningkatkan sumber Pendapatan Asli Daerah (PAD) yang dapat membiayai pengeluaran pemerintah dalam rangka menyelenggarakan pemerintahan daerah serta dapat menumbuhkembangkan daerah dalam berbagai bidang antara lain : meningkatkan pelayanan kepada masyarakat, menumbuhkan kemandirian daerah, dan meningkatkan daya saing daerah dalam proses pertumbuhan. (Widjaya, 2002)

Salah satu upaya untuk meningkatkan pendapatan asli daerah adalah dengan memgoptimalkan salah satu sektor pariwisata. Karena sektor pariwiwsa adalah salah satu sektor yang menjadi sumber pendapatan Negara terlebih khusus untuk pemerintah daerah. Karena sektor pariwisata yang berada di suatu daerah atau tempat wisata itu berada akan mendapatkan penghasilan dari wisata tersebut sehingga diharapka bisa meningkatkan 
pendapatan asli daerah tersebut. Bukan hanya itu sektor parwisiata juga mempunya fungsi yang lain yaitu meningkatkan perekonomian masyarakat sekitar daerah wisata tersebut karena dengan adanya wisata masyarakat akan banyak membuka bisnis toko-toko souvenir, oleh-oleh, agent travel dan lainlain. Selain itu berwisata sekarang ini juga sudah menjadi kebutuhan masingmasing individu.

Alasannya, karena berwisata akan membuat seseorang menjadi leih fresh, menghilangkan kejenuhan dari berbagai aktivitas sehari-hari yang telah dilakukan dengan relaksasi olahraga, berbelanja, bermain wahana, menikmati wisata alam, ataupun belajar mengenai sejarah sehingga bisa menjaga kesehata jasmani dan rohani. Jika seseorang tersebut mempunyai kedudukan ekonomi yang tinggi,pendidikan yang tinggi dan waktu luang yang banyak juga maka hal tersebut akan mendorong seorang individu untuk sering berwisata

Sektor pariwisata memiliki karakteristik yang unik karena dilihat bukan berdasarkan produknya, melainkan konsumennya, yaitu wisatawan. Sehubungan dengan hal tersebut, Goeldner dan Ritchie berendapat bahwa factor paling penting dalam kepariwisataan adalah wisatawan dan pengalaman yang ingin diperoleh wisatawan ketika mengunjungi suatu destinasi wisata(Antariska, 2016).

Kabupaten Lamongan merupakan salah satu kota di Propinsi Jawa Timur yang juga mendapat hak otonomi daerah untuk mengelola dan mengatur sumber pendapatan daerahnya. Salah satu upaya pemerintah Kabupaten Lamongan dalam meningkatkan PAD adalah melalui pemungutan pajak daerah. Karena Pajak sebagai salah satu sumber PAD yang penting, ditingkatkan potensi dan prospeknya, antara lain dengan melakukan kebijaksanaan yang akan ditempuh, yaitu lebih mengoptimalkan sumbersumber pajak memperbanyak mengelola di sektor pariwisata yang mana sektor tersebut juga bisa memnyumbangkan pendapatan asli daerah Kabupaten Lamongan. menurut Peraturan Daerah Kabupaten Lamongan No. 12 Tahun 2010 terdiri dari : Pajak Hotel, Pajak Restoran, Pajak Hiburan, Pajak Reklame, Pajak Penerangan Jalan, Pajak Parkir, pajak mineral bukan logam, pajak air tanah, pajak mineral bukan logam, pajak sarang burung wallet, dan pajak bumi dan bangunan pedesaan atau perkotaan.

Kabupaten Lamongan memiliki lumayan banyak obyek wisata mulai dari wisata alam yaitu lautnya, wisata sejarahnya, sampai wisata religious juga terdapat di Kabupaten Lamongan. Untuk perkembangan obyek wisata di setiap tahunnya mengalami peningkatan meskipun tidak signifikan tetapi tidak pernah mengalami penurunan. Sedangkan untuk wisatawan menurut data yang telah di publikasi oleh Badan Pusat Statistik Kabupaten Lamongan terdapat hasil kalau di setiap tahunnya mengalami naik turun. Berikut adalah jumlah obyek wisata dan jumlah wisatawan tahun 2005-2017:

Tabel 1. Jumlah Wisatawan dan Jumlah Obyek Wisata 


\begin{tabular}{ccc}
\hline Tahun & $\begin{array}{c}\text { Jumlah } \\
\text { wisatawan }\end{array}$ & Jumlah Obyek Wisata \\
\hline 2002 & 539380 & 3 \\
2003 & 569880 & 3 \\
2004 & 529857 & 3 \\
2005 & 570422 & 3 \\
2006 & 490105 & 3 \\
2007 & 1762935 & 4 \\
2008 & 1800199 & 4 \\
2009 & 2122233 & 4 \\
2010 & 1989000 & 4 \\
2011 & 1650734 & 4 \\
2012 & 1218907 & 4 \\
2013 & 3584250 & 6 \\
2014 & 2358468 & 8 \\
2015 & 2360913 & 8 \\
2016 & 2329732 & 8 \\
2017 & 2342557 & 8 \\
\hline
\end{tabular}

Sumber: BPS Lamongan, 2017

Tujuan dari penelitian ini adalah Untuk mengetahui pengaruh perkembangan jumlah wisatawan, jumlah obyek wisata, dan jumlah pengunjung hotel terhadap Pendapatan Asli Daerah Kabupaten Lamongan. Dan Untuk mengetahui pengaruh jumlah wisatawan, jumlah obyek wisata dan jumlah pengunjung hotel Kabupaten Lamongan.

Penelitian (Qadarrachman, 2010) dengan judul Analisis Penerimaan Daerah dari Sektor Pariwisata di Kota Semarang dan Faktor-faktor yang Mempengaruhinya. Hasil penelitian ini diketahui bahwa keempat variabel independen yaitu jumlah obyek wisata, jumlah wisatawan, tingkat hunian hotel dan juga pendapatan perkapita secara bersama-sama berpengaruh terhadap penerimaan daerah sektor priwisata di Kota Semarang diterima. Secara parsial variabel jumlah obyek wisata, jumlah wisatawan, dan tingkat hunian hotel berpengaruh signifikan.

Penelitian (Fitri, Ansofino \& Areva, 2014) dengan judul Pengaruh Sektor Priwisata Terhadap Pendapatan Asli Daerah Di Kabupaten Pesisir Selatan. Hasil dari penelitian ini adalah tidak adanya pengaruh positif dan signifikan antara jumlah wisatwan terhadap pendapatan asli daerah Kabupaten Pesisir Selatan. Sedangkan sarana akomodasi dan tempat belanja tourist mempunyai pengaruh yang positif dan signifikan terhadap pendapatan daerah Kabupaten Pesisir Selatan.

Penelitian (Yanti \& Hadya, 2018) dengan judul kontribusi sektor pariwisata terhadap peningkatan PAD di Kota Padang. Adapun hasil dari penelitian ini adalah analisis korelasi menunjukkan jumlah wistawan, retribusi objek wisata memiliki hubungan yang kuat dan signifikan terhadap 
peningkatan PAD Kota Padang. Sedangkan jumlah UKM tidak memiliki hubungan yang kuat dan signifikan terhadap peningkatan PAD Kota Padang.

Pendapatan Asli Daerah (PAD) sebagai salah satu sumber penerimaan daerah yang bersangkutan harus ditingkatkan seoptimal mungkin dalam rangka mewujudkan semangat kemandirian lokal. Anggaran Pendapatan Belanja Daerah (APBD) merupakan suatu rencana operasional keuangan daerah, disatu pihak menggambarkan penerimaan pendapatan daerah dan dilain pihak merupakan pengeluaran untuk membiayai pengeluaran rutin dan pengeluaran pembangunan dalam satu tahun anggaran(Oktafia, Soelistyo, \& Zainal, 2018).

Dalam rangka upaya peningkatan dan menggali sumber penerimaan daerah, pemerintah Kabupaten/Kota di Provinsi Nusa Tenggara barat secara aktif berusaha menggali dan meningkatkan sumber penerimaan daerah terlebih pendapatan yang berasal dari daerah- daerahnya sendiri(Mafahir \& Soelistyo, 2016).

Meskipun pemerintah daerah telah diberi otonomi secara luas dan desentralisasi fiscal, namun pelaksanaan otonomi tersebut harus tetap berada dalam koridor hokum Negara Kesatuan Republik Indonesia (NKRI). Dalam hal sumber penerimaan yang menjadi hak pemerintah daerah, Undang-undang no.32 Tahun 2004 tentang Pemereintah Daerah; dan Undang-undang nomer 33 tahun 2004 tentang perimbaangan keuangan antara pemerintah pusat dan darah telah menetapkan sumber-sumber penerimaan daerah (Mahmudi, 2010)

Pariwisata merupakan bagian yang tidak terpisahkan dari kehidupan manusia terutama dalam kegiatan sosial dan ekonomi (Kumala, Soelistyo, \& Nuraini, 2017)

Desentralisasi fiskal memberikan banyak kewenangan pada daerah guna menggali potensi yang dimilikinya sebagai sumber pendapatan suatu daerah tersebut (Kumala et al., 2017)

Dalam mengelola pemerintahannya, daerah memerlukan penilaian untuk melihat apakah pengelolaan keuangan sudah dilakukan secara efisien dan efektif dengan cara menilai kinerja pengelolaan keuangan daerah(Aisza, Alfi, \& Nuraini, 2018)

\section{METODE PENELITIAN}

Penelitian ini menggunakan metode penelitian deskriptif kuantitatif Merupakan analisis yang dapat diukur dan dihitung yang merupakan angkaangka. Penelitian ini di lakukan di provinsi Jawa Timur yaitu tepatnya di Kabupaten Lamongan. Alasan pemilihan penelitian di Kabupaten Lamongan dilakukan secara sengaja, karena Kabupaten Lamongan memulai untuk mengembangkan pada sektor pariwistanya. Dalam penelitian ini jenis data yang di gunakan adalah data sekunder yang di peroleh dri publikasi Badan Pusat Statistik (BPS) Kabupaten Lamongan. Alasan memilih kabupaten Lamongan karena Kabupaten Lamongan sebagai tempatnya adalah karena keunikan dari Kabupaten Lamongan seperti kita ketahui bahwa Kabupaten Lamongan termasuk Kabupaten yang bisa di katakana belum sepenuhnya maju. Tetapi disisi lain Kabupaten Lamongan sedang memulai untuk mengembangkan wisatanya. 
Dalam penelitian ini pengambilan data digunakan teknik dokumentasi. Dalam penelititan ini digunakan kontrak dengan cara yang di tentukan adalah termasuk definisi operasional. Penelitian ini menggunakan data yang di peroleh dari publikasi Badan Pusat Statistik Kabupaten Lamongan. Data yang di gunakan adalah Pajak daerah, Jumlah Obyek Wisata, Jumlah Wisatawan dan Jumlah Pengunjung Hotel tahun 2005-2017. Definisi operasional yang terdapat dalam penelitian ini adalah :

1. Pendapatan Asli Daerah

Pendapatan Asli Daerah Kabupaten Lamongan yang di dapatkan langsung dari Badan Pusat Statistik dari tahun 2005-2017.

2. Jumlah Wisatawan

Adalah banyaknya jumlah orang yang berwisata baik nusantara ataupun Luar Negeri.

3. Jumlah Obyek Wisata

Adalah jumlah banyaknya wisata baik wisata alam, wisata buatan dan wisata religi. Yang berada di kabupaten Lamongan yang sudah di data oleh BPS kabupaten Lamongan.

4. Jumlah Pengunjung Hotel

Adalah jumlah pengunjung hotel baik dari domestic/tourist yang telah berkunjung ke Kabupaten Lamongan.

Alat analisis data yang digunakan dalam penelitian ini adalah analisis regresi berganda yang diestimasi dengan metode kuadrat terkecil biasa (OLSOrdianary Least Squares), karena metode ini mempunyai sifat-sifat yang dapat diunggulkan, yaitu secara teknis sangat kuat, mudah dalam penarikan interpretasi dan perhitungannya, serta sifat penaksir yang blue (Damodar N. Gudjarati, 2015)

Tujuan dari penggunanaan regresi linier berganda ini adalah untuk mengetahui adanya pengaruh antar variabel dependent dan variabel independent.

Model yang digunakan untuk mengestimasi fungsi Pendapatan Asli Daerah sebagai berikut :

Pendapatan Asli Daerah $(Y)=(X 1, X 2, X 3,) \ldots \ldots \ldots \ldots \ldots(1)$

Penerimaan Pajak Daerah diartikan sebagai fungsi produksi sehingga penulisan secara matematisnya adalah sebagai berikut :

$\mathrm{Y}=X 1^{\alpha 1} \cdot X 2^{\alpha 2} \cdot X 3^{\alpha 3}$

Keterangan :

$Y \quad=$ Variabel dependen

$\alpha 1-\alpha 3=$ Koefisien regresi dari masing-masing variabel independen terhadap pajak daerah.

$\mathrm{X} 1=$ Jumlah Wisatawan

X2 = Jumlah Obyek wisata 
X3 = Jumlah Pengunjung Hotel

\section{Uji Multikolienaritas}

Uji Multikolinearitas, untuk menguji ada atau tidaknya korelasi antara variabel-variabel dependen apabila nilai $\mathrm{R}$-squared yang dihasilkan sangat tinggi.

\section{Uji Normalitas}

Uji Normalitas, untuk menguji apakah variabel independen dan variabel dependen memiliki distribusi normal atau mendekati normal.

Hipotesis yang diuji :

$\mathrm{HO}=$ Error berdistribusi Normal

$\mathrm{H} 1 \quad=$ Error tidak berdistribusi normal

\section{Uji Autokorelasi}

Uji Autokorelasi, adalah menggunakan uji Durbin-Watson yaitu untuk mengetahui apakah ada atau tidak korelasi antara variabel-variabel dependen terhadap variabel independen.

Hipotesis yang diuji :

$\mathrm{HO} \quad=$ tidak terdapat autokorelasi

$\mathrm{H} 1$ = terdapat autokorelasi

\section{HASIL DAN PEMBAHASAN}

\section{Kondisi Geografis Kabupaten Lamongan}

Secara geografis Kabupaten Lamongan terletak pada $6^{\circ} 51^{\prime}-7^{\circ} 23^{\prime}$ Lintang selatan dan $112^{\circ} 33^{\prime}$ - $112^{\circ} 34^{\prime}$ Bujur Timur. Kabupaten Lamongan memiliki luas wilayah kurang lebih $1.812,8 \mathrm{~km} 2$ atau $\pm 3.78 \%$ dari luas wilayah provinsi Jawa Timur dengan panjang garis pantai sepanjang $47 \mathrm{~km}$, maka wilayah perairan laut Kabupaten Lamongan adalah seluas $902,4 \mathrm{~km} 2$, apabila dihitung 12 mil dari permukaan laut.

Daerah Kabupaten Lamongan daratannya terbagi menjadi 3 bagian, dan daratannya juga terdapat belahan dari bengawan solo :

1. Bagian tengah selatan digolongkan menjadi bagian yang bis dikatakan agak subur

2. Bagian selatan digolongkan menjadi bagian yang mempunyai kondisi pegnungan berkapur.

3. Bagian tengah utara tergolong menjadi bagian yang dikenal dengan rawan banjir.

4. Sedangkn wiayah administrative Kabupaten Lamongan dibatesi oleh Kota Gresik, Jombang Kediri, Mojokerto, Bojonegoro dan Tuban.

Kabupaten Lamongan terdiri dari 27 kecamatan dengan memiliki luas wilayah kurang lebih $1.812,80 \mathrm{Km}^{2}$ setara $181.280 \mathrm{Ha}$ atau $+3.78 \%$ dari luas wilayah Propinsi Jawa Timur dengan panjang garis pantai sepanjang $47 \mathrm{Km}$, dengan wilayah perairan laut Kabupaten Lamongan asdalah seluas 902,4 km2, 
apabila dihitung 12 mil dari permukaan laut. Kondisi topografi Kabupaten Lamongan dapat ditinjau dari ketinggian wilayah di atas permukaan laut dan kelerengan lahan. Kabupaten Lamongan terdiri dari daratan rendah dan lahan bonorowo dengan tingkat ketinggian sekitar 20 meter.

Karena letaknya yang strategis ini menjadikan Kabupaten Lamongan sebagai Kabupaten yang di kembangkan guna meningkatkan perekonomian dan masuknya investasi dari Provinsi Jawa Timur yang sering disebut dengan wilayah pengembangan Gerbang Kertosusila (Gersik Bangkalan Mojokerto Surabaya Sidoarjo Lamongan).

\section{Potensi Pariwisata Kabupaten Lamongan}

Kabupaten Lamongan yang merupakan salah satu Daerah Tujuan Wisata (DTW) di Jawa Timur selain itu, juga memiliki daya tarik yang besar, yaitu alamnya dan budaya yang dimiliki.

Salah satu daya Tarik alamnya yang sangat dikenal adalah Pantai Tanjung Kodok yang sekarang sudah dibangun sehingga Pantai Tanjung Kodok ini berada di kawasan Wisata Bahari Lamongan (WBL) tidak hanya itu baru-baru ini pantai yang ramai dengan wisatawannya yaitu ada pantai LORENA. Tidak hanya itu di Kabupaten Lamongan juga terdapat daerah wisata religi yang termasuk daya Tarik budaya yaitu Makam Sunan Drajad dan museum Sunan Drajad ada juga Makam Sunan Sendang.

Jumlah wisatawan di Kabupaten Lamongan pada tahun 2005-2017 mengalami peningkatan, hanya di tahun 2014 jumlah wisatawan dari tahun sebelumnya berjumlah 3.584.250 orang turun menjadi 2.358 .468 orang.

Pariwisata di Kabupaten Lamongan terdiri dari wisata alam, buatan dan juga budaya. Wisata alam terdiri dari pantai lorena, pantai tanjung kodok, pantai kutang dan Goa Maharani sedangkan wisata buatan terdiri dari Wisata Bahari Lamongan, Maharani Zoo, Waduk Gondang selain itu wisata budaya nya juga terdapat Makam Dunan Drajad dan Makam Sunan Sendang. Jadi wisata yang terdapat di Kabupatan Lamongan pada tahun 2017 yang terdapat pada data adalah sebagai berikut :

\section{Tabel 4. Jumlah Obyek Wisata}

Tahun Obyek wisata

Makam Sunan Drajad, Wisata Bahari
Lamongan,Goa Maharani,Waduk
Gondang, Museum Sunan Drajad,
Brumbun, Museum Sunan Sendang,
Museum Vanderwick

Berdasarkan tabel diatas dapat diketahui bahwa data obyek wisata di Kabupaten Lamongan tahun 2017 mengalami peningkatan dari tahun-tahun sebelumnya.

Dari penelitian diatas dapat diketahui perkembangan jumlah wisatawan, jumlah obyek wisata dan jumlah pengunjung hotel masing-masing mengalami peningkatan di setiap tahunnya. 
Untuk X1 jumlah wisatawan mulai dari tahun $2002-2005$ jumlah wisatawan terus meningkat dan pada tahun 2006 jumlah wisatawan mengalami penurunan yaitu jumlah wisatawan di tahun 2006 hanya sebesar 490105 orang. Tetapi di tahun 2007-2013 jumlah wisatawan terus meningkat yaitu puncaknya di tahun 2013 jumlah wisatawan mencapai 3584250 orang. Dan di tahu 2014-2017 jumlah wisatawan tidak sebanyak di tahun 2013. Jadi, dapat disimpulkan jumlah wisatawan paling banyak berada di tahun 2013

Untuk X2 jumlah obyek wisata mulai dari tahun 2002-2006 obyek wisata yang terdata hanya ada 3 obyek, di tahun 2007-2012 mengalami peningkatan 1 obyek yaitu menjadi 4 obyek wisata. Dan di tahun 2013 mengalami kenaikan yaitu 2 obyek sehingga menjadi 6 obyek wisata di tahun 2013. Di tahun 2014-2017 obyek wisata mengalami kenaikan sebesar 2 yaitu menjadi 8 obyek wisata.

Untuk X3 jumlah pengunjung Hotel mulai dari tahun 2002-2009 perkembangan jumlah pengunjung hotel selalu mengalami kenaikan. Tetapi di tahun 2010 jumlah pengunjung hotel hanya sebesar 9729 orang, di tahun selanjutnya 2011-2017 pengunjung hotel mengalami peningkatan lagi. Jadi, kesimpulannya di tahun 2010 pengunjung hotel adalah paling sedikit yaitu sebesar 9729 orang sedangkan pengunjung hotel paling banyak berada di tahun 2013 yaitu mencapai 51929 orang.

\section{Analisis Uji Asumsi Klasik}

Untuk mencari tahu/mengetahui apakah model tersebut bisa dikatakan relevan atau tidak maka, lebih dulu dilakukan pengujian variabel terhadap uji asumsi klasik.

\section{Uji multikoliniearitas}

Dalam uji multikolinearitas analisis data time series dapat diketahui hasil yang didapat adalah:

Tabel 4. Hasil Uji Multikolinearitas

\begin{tabular}{lll}
\hline Variabel Penjelas & Nilai R-Squared $\left(\boldsymbol{R}^{2}\right)$ \\
\hline & $R^{2} 0,639204$ & $<$ \\
Jumlah Wisatawan (X1) & $R^{2}$ model & \\
& $R^{2} 0,5575918$ \\
Jumlah Obyek Wisata (X2) & $R^{2}$ model & \\
Jumlah Pengunjung Hotel & $R^{2} 0,935918$ \\
(X3) & $R^{2}$ model & \\
\end{tabular}

Sumber: Pengolahan Data Dengan Program e-views 9

Berdasarkan Tabel 4 diatas dapat diketahui bahwa variabel jumlah Wisatawan (X1), Jumlah Obyek Wisata (X2) dan variabel jumlah pengunjung hotel (X3) tidak terdapat multkolinearitas atau bebas multikolinearitas dimana $R^{2}$ hasil dari auxiliary regression lebih kecil dari $R^{2}$ model utama.

Uji Normalitas. Dalam uji normalitas analisis data time series dapat diketahui hasil sebagai berikut : 


\section{Gambar 4. Hasil Uji Normalitas}

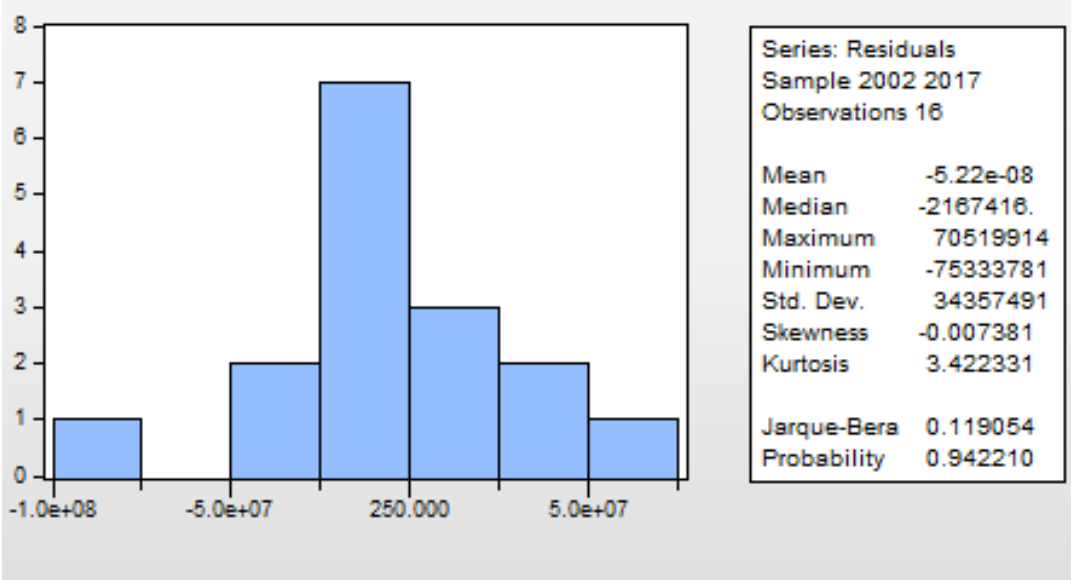

Sumber: pengolahan data dengan program e-views-9

Berdasarkan hasil output diperoleh p-value uji Jarque-bera $=0,119054$. Nilai tersebut $>0,05$ sehingga diputuskan untuk menerima H0. Dengan demikian dapat disimpulkan bahwa asumsi normalitas residual terpenuhi karena error berdistribusi normal.

Uji Autokorelasi

Dalam uji autokorelasi data time series dapat diketahui hasil sebagai berikut :

\section{Tabel 4.Uji Durbin-watson}

Gagal

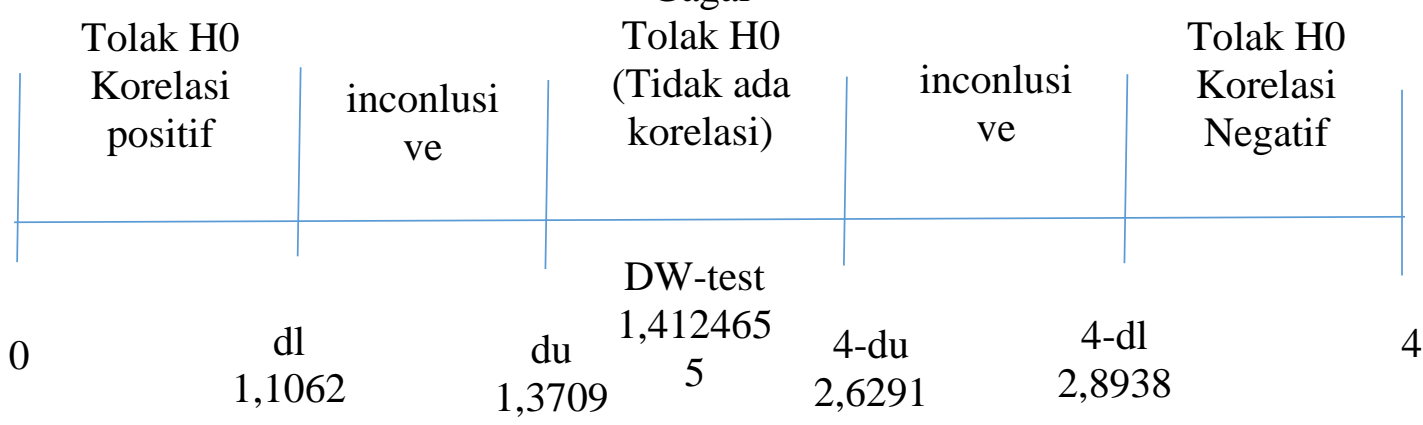

Sumber: Pengolahan Data Dengan Program e-views 9

Dari tabel 4.4 diatas diperoleh nilai statistik Uji durbin-watson untuk model ini adalah $\mathrm{d}=$ sebesar 1,41246 maka hasil $\mathrm{dw}$ berada di daerah $\mathrm{du}>\mathrm{dw}$ $<$ 4-du, maka H0 ditolak jadi terdapat autokorelasi. 


\section{Uji Heteroskesdatisitas}

Dalam analisis data time series dapat diketahui hasil sebagai berikut :

Tabel 4 Hasil Uji Heteroskesdatisitas

\begin{tabular}{lc}
\hline Obs*R-squared pada Uji White & $\alpha$ \\
\hline 12,95784 & 0,005
\end{tabular}

Sumber: Pengolahan Data Dengan Program e-views 9

Berdasarkan uji white diatas diperoleh nilai Prob.Chi-Square adalah 0,1645 yang mana lebih besar dari 0,05 , sehingga diputuskan untuk menerima H0. Dengan demikian asumsi non-heteroskesdastisitas tidak dilanggar.

Analisis Regresi Linier Berganda

Hasil persamaan Regresi Linier Berganda :

\section{Gambar 4. Hasil Persamaan Regresi Linier Berganda}

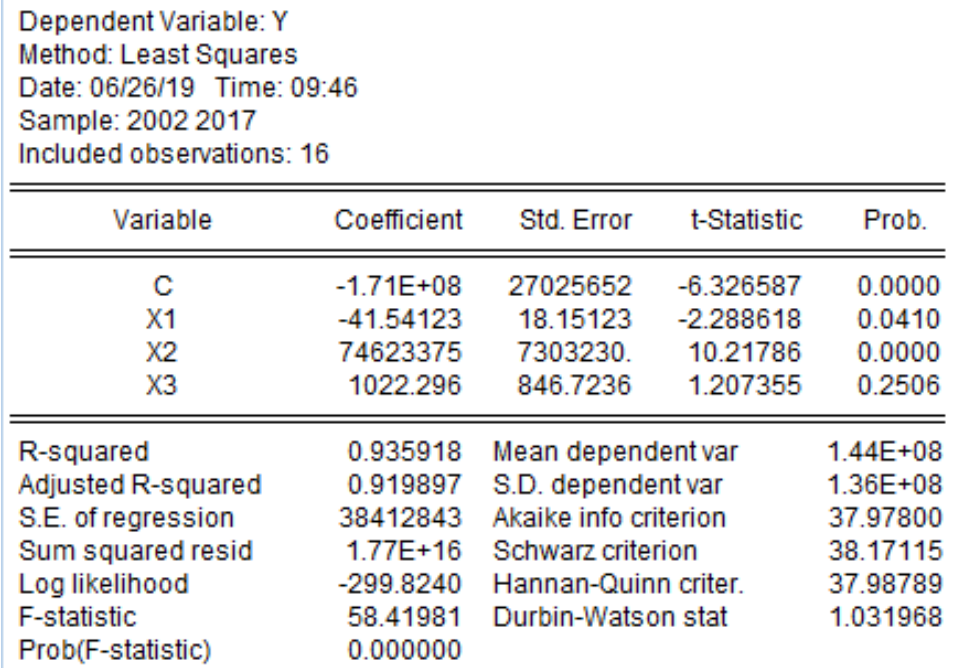

Sumber: Pengolahan Data Dengan Program e-views 9

\section{Uji Statistik T}

Berdasarkan hasil analisis didapatkan nilai t-statisttic X1 (Jumlah Wisatawan) $=-2,288618, \mathrm{X} 2($ Jumlah Obyek wisata $)=10,21786)$ dan X3 (jumlah pengunjung hotel) $=1,207355$. Nilai t-statistic Jumlah wisatawan $2,288618<$ t-tabel 1,771

Artinya Jumlah wisatawan mempengaruhi Pendapatan Asli Daerah Kabupaten Lamongan tetapi diduga faktor lain sehingga hasil dari prob-t negative atau contohnya yaitu karena pendapatan jumlah wisatawan tidak di setorkan oleh pihak pengelola wisata ke pihak Pemerintah Daerah (PAD). Sedangkan Nilai t-statistic Jumlah Obyek wisata $=10,21786>$ t-tabel 1,771 sehingga diputuskan untuk menerima H0. Artinya banyaknya Obyek wisata 
mempengaruhi Pendapatan Asli Daerah Kabupaten Lamongan dan nilai tstatistic Jumlah pengunjung hotel $=1,207355<$ t-tabel 1,771 sehingga diputuskan untuk menerima H0. Artinya banyaknya jumlah pengunjung hotel tidak mempengaruhi Pendapatan Asli Daerah Kabupaten Lamongan. Berikut kurva dari Uji T :

\section{Kurva Jumlah Wisatawan :}

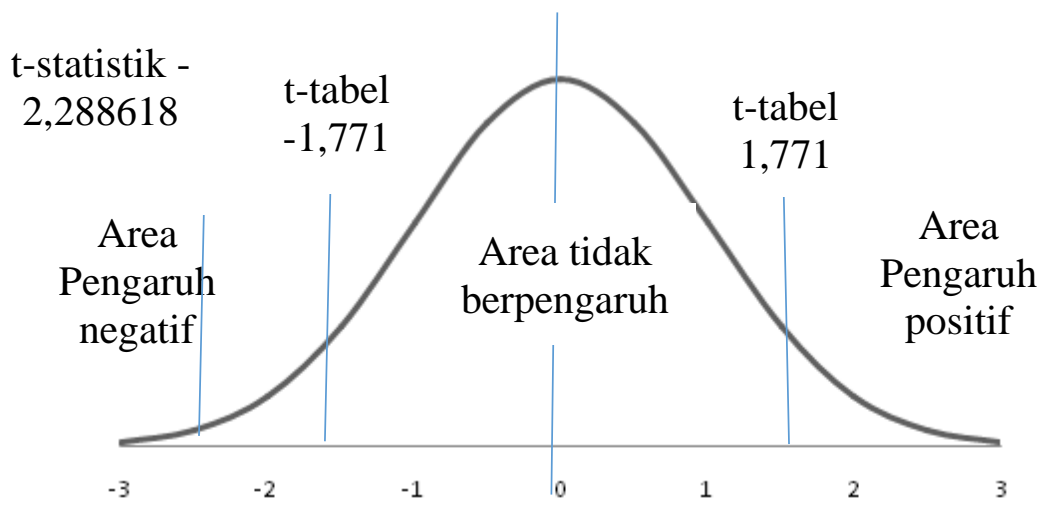

\section{Kurva Jumlah Obyek Wisata}

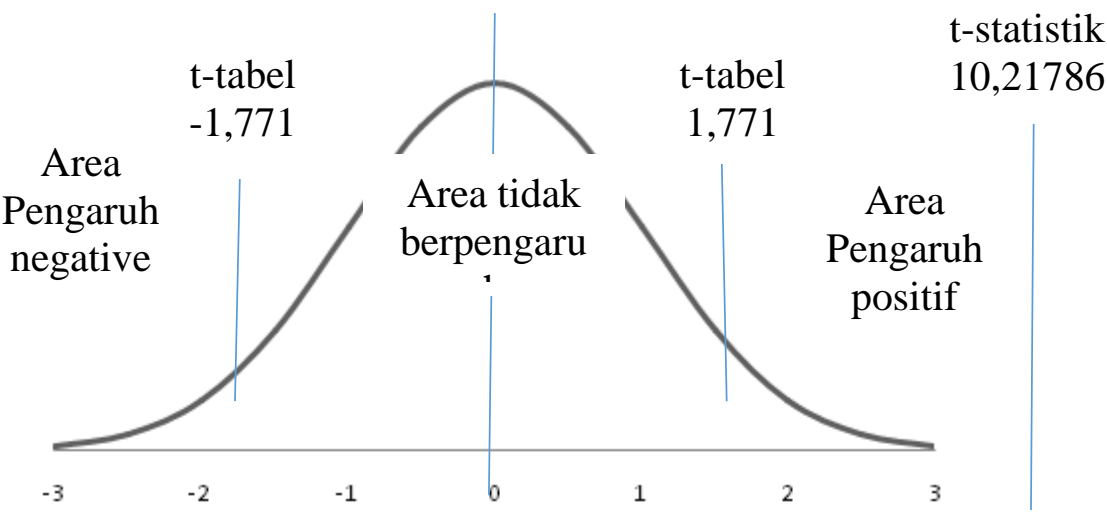




\section{Kurva Jumlah Pengunjung Hotel}

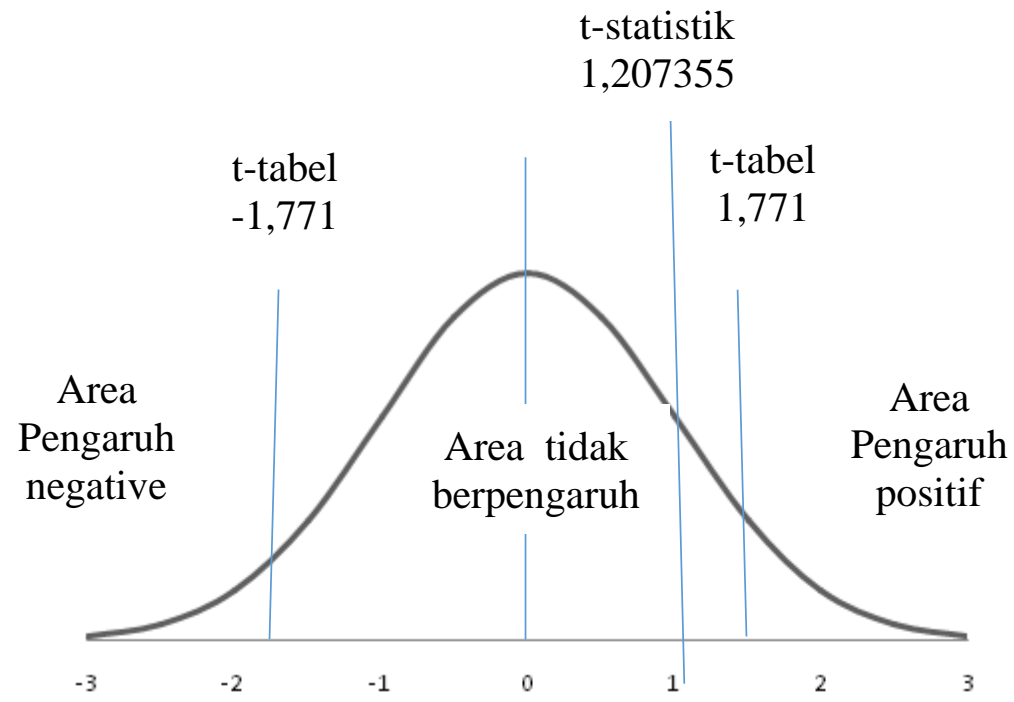

\section{Uji Statistik F}

Berdasarkan hasil analisis didapatkan nilai prob $($ F-statistic $)=0,000$. Nilai tersebut $<(0,05)$, sehingga diputuskan untuk menolak H0. Oleh karena itu dapat disimpulkan bahwa minimal ada satu diantra jumlah wisatawan, jumlah obyek wisata dan jumlah pengunjung hotel mempengaruhi Pendapatan Asli Daerah Kabupaten Lamongan.

\section{Koefisien Determinasi}

Koefisien dari determinasi yang dikatakan bahwa $R^{2}$ merupakan suatu ukuran yang dapat mengnformasikan baik atau tidaknya suatu model regresi yang telah terestimasi. Dengan kata lain, angka tersebut dapat mengukur seberapa garis regresi yang telah terestimasi dengan sesungguhnya. Suatu penelitian banyak yang menggunakan nilai adjusted $R^{2}$ karena dapat naik atau turun jika suatu variabel ditambah dalam suatu model.

Hasil pengujian menggunakan time series menghasilkan nilai adjusted $R^{2}$ sebesar 0,935918 atau sebesar $93,5918 \%$ yang dapat diartikan bahwa sebanyak 93,5918\% variasi atau perubahan pada pendapatan asli daerah Kabupaten Lamongan yng terdapat pada variabel independen yang ada, sedangkan sisanya $6,4082 \%$ dapat dijelaskan oleh sebab lain yang ada dalam penlitian ini.

Berdasarkan hasil penelitian ini menunjukkan perkembangan Jumlah Wisatawan dan Jumlah Pengunjung Hotel mengalami naik turun disetiap tahunnya. Berbeda dengan jumlah obyek wisata di setiap tahunnya selalu mengalami peningkatan. 
Untuk Uji Asumsi Klasik X1 yaitu Jumlah Wisatawan berpengaruh signifikan terhadap Y yaitu Pendapatan Asli Daerah Kabupaten Lamongan. Sehingga hipotesis yang menyatakan bahwa adanya pengaruh Jumlah wisatawan terhadap Pendapatan Asli daerah Kabupaten Lamongan dapat diterima. Menurut Organisasi Wisata Dunia (WTO) wisatawan adalah orang yang melakukan perjalanan ke suatu Daerah atau Negara asing dan menginap minimal 24 jam atau maksimal enam bulan di tempat tersebut. Lewat industry ini, banyak negara diselamatkan dari serangkaian krisis-krisis ekonomi yang terjadi (Antariksa, 2016). Tetapi penelitian ini tidak sejalan dengan penelitian Fitri (2014) dimana tidak ada pengaruh yang signifikan oleh Jumlah Wisatawan terhadap Pendapatan Asli Daerah yang artinya apabila jumlah wisatawan naik satu persen maka tidak ada pengaruh terhadap Pendapatan Asli Daerah. Hal ini terjadi karena kenaikan jumlah wisatawan yang tidak terlalu besar setiap tahunnya.

Bersakarkan penelitian ini menunjukkan bahwa X2 yaitu Jumlah Obyek Wisata berpengaruh positif dan signifikan terhadap Y yaitu Pendapatan Asli Daerah Kabupaten Lamongan. Sehingga hipotesis yang menyatakan bahwa adanya pengaruh Jumlah Obyek wisata terhadap Pendapatan Asli daerah Kabupaten Lamongan dapat diterima. Penelitian ini sejalan dengan penelitian Qaddarochman (2010) dimana jumlah obyek wisata berpengaruh positif dan signifikan terhadap Pendapatan Asli Daerah.

Berdasarkan penelitian ini menunjukkan bahwa X3 yaitu Jumlah Pengunjung Hotel berpengaruh postif tidak signifikan terhadap Y yaitu Pendapatan Asli Daerah Kabupaten Lamongan. Sehingga hipotesis yang menyatakan adanya pengaruh Jumlah Pengunjung Hotel terhadap Pendapatan Asli Daerah Kabupaten Lamongan tidak diterima. Sector pariwisata terutama kegiatan yang berkaitan dan penginapan yaitu hotel, baik berbintang ataupun melati akan memperoleh pendapatan yang semakin banyak apabila para tourist/wisatawqan tersebut semakin lama menginap (Badrudin, 2001).. Variabel Jumlah Pengunjung Hotel memiliki pengaruh yang tidak signifikan terhadap Pendapatan Asli daerah Kabupaten Lamongan dikarenakan jumlah pengunjung hotel yang tidak banyak karena kebanyakan pengunjung wisata tersebut berasal dari masyarakat local yang artinya mereka tidak perlu menginap di hotel.

\section{KESIMPULAN}

Berdasarkan permasalahan dan pernyataan diatas atau pada hasil penelitian yang telah diuraikan maka dapat dihasilkan kesimpulan sebagai berikut :

Faktor yang mempengaruhi Pendapatan Asli Daerah secara signifikan Kabupaten Lamongan adalah jumlah obyek wisata. Sedangkan jumlah wisatawan dan jumlah pengunjung hotel tidak mempunyai pengaruh yang signifikan terhadap Pendapatan Asli Daerah. 
Jumlah wisatawan tidak berpengaruh positif dan signifikan terhadap Pendapatan Asli Daerah Kabupaten Lamongan, yang ditunjukkan pada nilai t-hitung $-1,929754<\mathrm{t}$ tabel sebesar 2,228. Dengan nilai signifikan 0,0857 > 0,005. Maka menolak H1 dan menerima H0. Yang berarti apabila jumlah wisatawan menurun satu persen, maka tidak akan mempengaruhi pendapatan asli daerah Kabupaten Lamongan. Jumlah obyek wisata berpengaruh positif dan signifikan terhadap pendapatan asli daerah Kabupaten Lamongan, yang ditunjukkan pada nilai t-hitung 8,880829> t tabel sebesar 2,228. Dengan nilai signifikan 0,000 < 0,05. Maka menerima H1 dan menolak H0. Yang dapat diartikan apabila jumlah obyek wisata meningkat maka akan mempengauhi jumlah pendpatan asli daerah.

Jumlah pengunjung hotel tidak berpengaruh signifikan terhadap pendapatan asli daerah Kabupaten Lamongan, yang ditunjukkan pada nilai thitung 1,021321 < t tabel sebesar 2,228. Dengan nilai signifikan 0,3338>0,005. Maka menolak H1 dan Menerima H0. Yang berarti apabila jumlah pengunjung hotel mengalami penurunan maka tidak akan berpengaruh terhdap pendapatan asli daerah Kabupaten Lamongan.

\section{DAFTAR PUSTAKA}

Aisza, S., Alfi, F., \& Nuraini, I. (2018). Jurnal Ilmu Ekonomi ANALISIS PENGELOLAAN KEUANGAN DAERAH TERHADAP PRODUK DOMESTIK REGIONAL BRUTO ( PDRB ) DI KABUPATEN / KOTA PROVINSI KALIMANTAN SELATAN

Antariska, B. (2016). Kebijakan Pembangunan Kepariwisataan.

Damodar N. Gudjarati. (2015). Dasar-Dasar Ekonometrika. (S. Empat, Ed.). Jakarta.

Fitri, D., Ansofino, \& Areva, D. (2014). Pengaruh Sektor Pariwisata Terhadap Pendapatan Asli Daerah (PAD) di Kabupaten Pesisir Selatan, 0-14.

Kumala, M., Soelistyo, A., \& Nuraini, I. (2017). Analisis potensi sektor pariwisata sebagai sektor unggulan di wilayah jawa timur. Ilmu Ekonomi, 1(4), 474-481.

Mafahir, A., \& Soelistyo, A. (2016). Analisis Pengaruh Pad, Dau Dan Dak Terhadap Kemiskinan Pada Kabupaten/Kota Di Provinsi Sumatera Barat. Economica, 4(2), 193-216. https://doi.org/10.22202/economica.v4i2.633 Erlangga.

Mahmudi. (2010). Manajemen Keuangan Daerah. Jakarta: Penerbit

Oktafia, A. M., Soelistyo, A., \& Zainal, A. (2018). PENGARUH PENDAPATAN ASLI DAERAH ( PAD ), DANA ALOKASI UMUM ( DAU ), DANA ALOKASI KHUSUS ( DAK ) TERHADAP PRODUK DOMESTIK 
Qadarrachman, N. (2010). Analisis Penerimaan Daerah dari Sektor Pariwisata di Kota Semarang dan Faktor-Faktor yang Mempengaruhinya.

Widjaya, H. (2002). Otonomi Daerah dan Daerah Otonomi. Jakarta: P.T Raja Grafindo Persada.

Yanti, \& Hadya. (2018). Kontribusi Sektor Pariwisata Terhadap Peningkatan PAD di Kota Padang. 